\title{
Analysis of Factors Affecting Hedging Decision Making (Study in Pharmaceutical Sub-Sectors Listed in Indonesia Stock Exchange, 2009-2018)
}

\author{
Yuhasril, Yuhasril Hirdinis, M Sumiyarsih, Sumiyarsih \\ Trisakti School of Management
}

\begin{abstract}
This study aims to analyze the influence of the factors affecting hedging decision making (study on the pharmaceutical sub-sector listed on the Indonesian Stock Exchange 2009-2018). In conducting this research, the writer uses quantitative research methods with casual approaches. This study uses secondary data, namely annual financial report data published by pharmaceutical companies listed on the Indonesia Stock Exchange (IDX). The population used in this study were pharmaceutical companies listed on the Indonesia Stock Exchange in 20092018. The sampling technique in this study was purposive sampling and according to the predetermined criteria, it was obtained 4 sample companies from 10 populations who had data to be studied. This study uses a logistic regression model. The results of this study indicate that firm size has a positive and significant effect on hedging decisions, Profitability has a positive and significant effect on hedging decisions, liquidity has a negative and significant effect on hedging decisions, and leverage has a positive and significant effect on hedging decisions.

Keywords: hedging decision, firm size, profitability, liquidity, leverage
\end{abstract}

DOI: $10.7176 /$ RJFA/12-12-04

Publication date:June $30^{\text {th }} 2021$

\section{INTRODUCTION}

A company cannot avoid international business transactions because in order to meet the needs of its country it cannot fulfill all of it, so it is inevitable to conduct international business to complement the needs of its country. International business results in the exchange of goods and services transactions, one of which is export-import activities which causes currency exchange with other currencies in making business transaction payments. At any time the movement of currency values will fluctuate so that changes in the cash flow needed and used can occur.

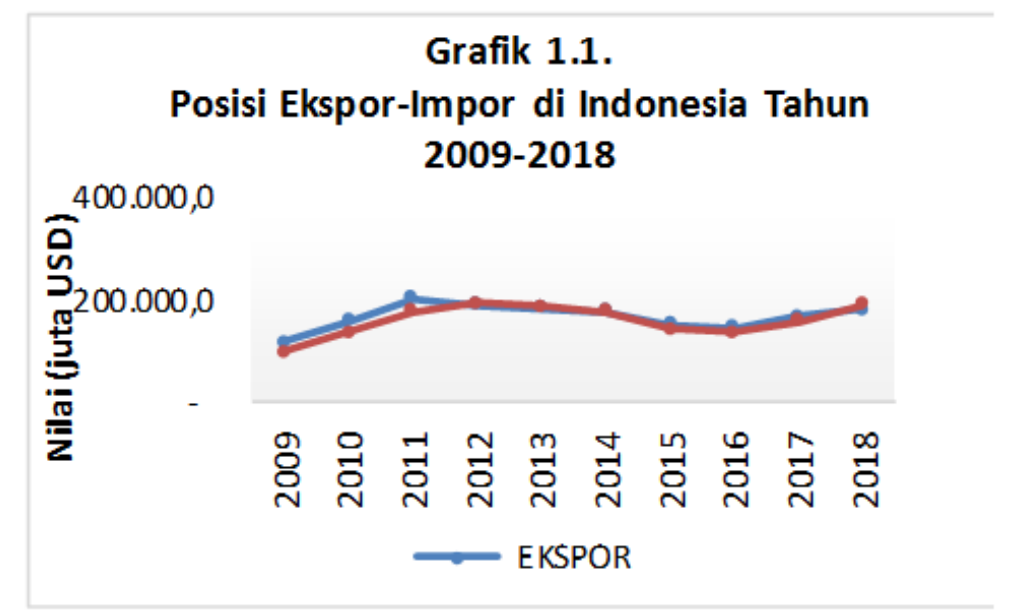

Source: Central Bureau of Statistics.

From Graph 1.1. shows an imbalance between imports and exports which is one of the burdens in Indonesia's trade balance in the period 2009 to 2018. Exports that are lower than imports have caused Indonesia's trade balance to experience a deficit throughout the year and reflect poor economic performance due to low productivity and dependence. against high imports.

The value of Indonesia's imports in December 2018 reached US \$ 15.28 billion, but increased by 1.16 percent compared to December 2017. 


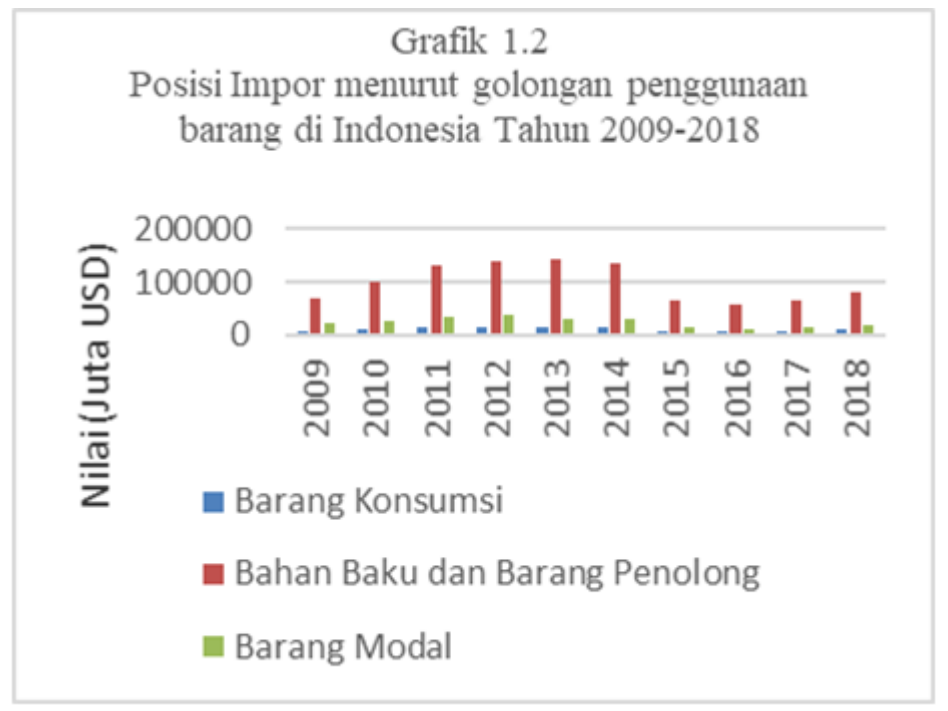

Source: Central Bureau of Statistics.

From Graph 1.2, the highest import activities during the period 2009 to 2018 were carried out to purchase raw materials and auxiliary goods. This indicates that the domestic industry is still highly dependent on imported goods. If the value of imports is higher than the amount of exports, it can cause the country to experience a deficit so that the exchange rate weakens.

Currency fluctuation is the fluctuation of the price of one currency compared to other currencies. Fluctuations or uncertainty in the exchange rate of the rupiah against foreign currencies can cause business risks, especially in companies whose activities cannot be separated from export-import activities so that managers make various efforts to reduce or eliminate these risks, one of which is by making hedging decisions.

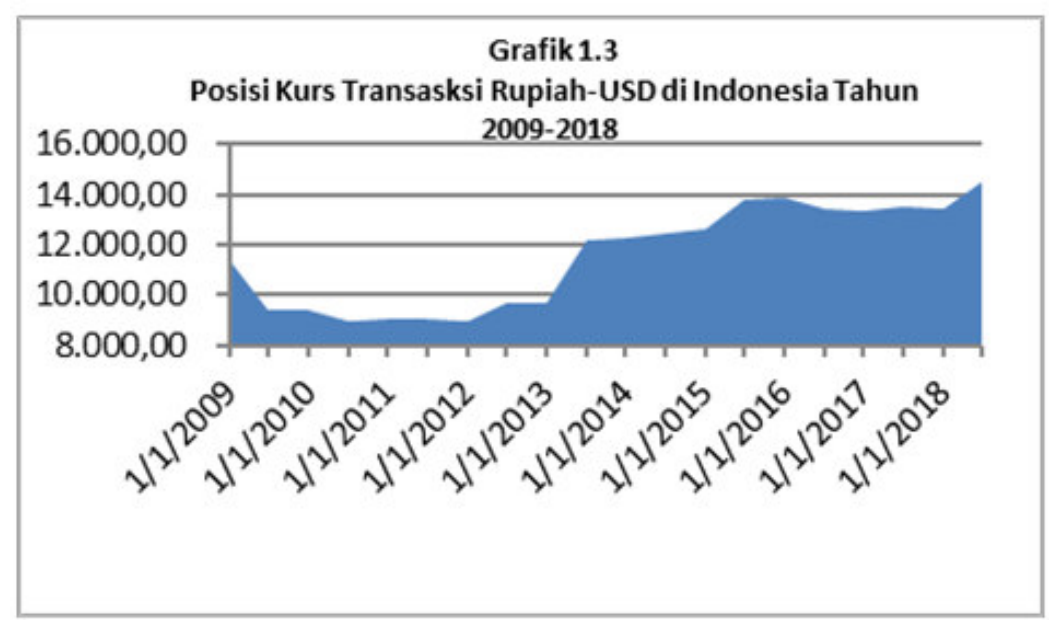

Source: Bank Indonesia.

From Figure 1.3, on January 1, 2009, the rupiah exchange rate per dollar was IDR 11,355.00. The peak of the weakening of the Rupiah against USD exchange rate over the past 10 years occurred in September 2018, which reached Rp. 14,929.00 per dollar.

The negative effect of the rupiah depreciation is unavoidable, especially for sectors that carry out a lot of import activity and have high debt ratios. The pharmaceutical industry is the sector most severely affected by the depreciation of the rupiah. Minister of Industry Airlangga Hartanto said that the pharmaceutical industry is the sector most severely affected by the weakening of the rupiah exchange rate, because some of its raw materials are imported and purchased in foreign currency (Airlangga Hartanto, 2018). The value of pharmaceutical production has reached USD 4.7 billion or equivalent to $27 \%$ of the total pharmaceutical market in Southeast Asia. Meanwhile in Indonesia alone, the pharmaceutical industry is able to provide $70 \%$ of the drug needs (Airlangga Hartanto, 2018). According to Siswanto, Head of the Health Research and Development Agency (Balitbangkes) of the Indonesian Ministry of Health, this is because almost $90 \%$ of the pharmaceutical industry in Indonesia still uses imported materials related to chemicals (API), because developing medicinal raw materials is not easy (Siswanto, 2019 ).

This phenomenon shows that pharmaceutical companies are still dependent on imports for medicinal raw materials. The high import value of medicinal raw materials is caused by the lack of strength in the basic chemical 
industry in Indonesia. Apart from that, the lack of competitiveness and the high cost of developing the chemical industry are also contributing factors.

Companies can carry out risk management in order to continue to bring profits in the morning amidst conditions of weakening rupiah exchange rate fluctuations. To minimize the loss of currency exchange rates, risk management of changes in currency exchange rates is needed by using hedging or hedging (Brams et al., 2018).

Hedging decision making is influenced by factors that come from external and internal to the company. External factors that influence hedging activities include the BI rate, exchange rate, and inflation, which are the company's references in hedging activities (Sunaryo, 2009).

The hedging decision is also influenced by internal factors of a company, such as firm size, profitability, liquidity and leverage. These internal factors will be carried out in this study to determine whether these internal factors really have an influence on the hedging decision.

\section{THEORITICAL REVIEW}

\subsection{Risk and Risk Management}

Risk is something that cannot be avoided and can arise at any time. Business risks can have an impact on the condition of the company either directly or indirectly. Risk has two characteristics, namely, it is uncertainty which if it occurs will cause losses, it can be concluded that the risk arises because of uncertainty (Hanafi, 2016: 62). Risk management is identifying events that can have adverse financial consequences and then taking action to prevent and or minimize losses caused by these events (Brigham and Houston, 2018).

\subsection{Foreign Exchange Exposure}

According to Munthe, Abraham Esra (2017) foreign exchange exposure is a measure of the potential changes in profitability, cash flow and market value of a company caused by changes in exchange rates. Exposure is a risk arising from fluctuations in foreign currencies that are no longer as expected, especially when converted into domestic currency. Meanwhile, according to (Larasati, 2017) exposure is a situation where a company cannot avoid the influence of fluctuations in foreign exchange values. Pharmaceutical companies are the most significant parties to receive the impact or risk impact from fluctuations in foreign currencies, because most of their raw materials come from abroad.

\subsection{Hedging}

Hedging is an action to protect the company against the risk of loss on foreign currency by reducing or avoiding it as a result of business transactions. Actions and hedging decisions are usually carried out in the context of anticipating fluctuations in foreign exchange (forex) on the market (Husna Anniyati, 2019). If a multinational company has decided to hedge all or part of its transaction exposure, the company can use hedging instruments in the form of futures contracts, forward contracts, currency swaps and options.

\subsection{Factors that influence hedging decisions}

In this study, observations will be made on internal factors that are thought to influence hedging decisions such as firm size, profitability, liquidity, and leverage.

a. Firm Size

The size of the company reflects how large the assets of the company are. Companies that have a large size tend to use large debt because these companies need funds that increase along with the growth of the company itself. b. Profitability

Profitability is the net result of various policies and decisions implemented by a company or the company's ability to generate profits from the sale of products or services produced by the company (Saraswati, 2019).

c. Liquidity

Liquidity is the company's ability to fulfill its financial obligations in the short term (Wiagustini, 2013: 85). According to Darmawi (2015: 59) Liquidity is a term used to show the supply of cash and other assets that can easily be turned into cash. Liquidity describes a company's ability to complete short-term obligations (Sofyan, 2015: 301).

d. Leverage

Leverage in the financial world is the company's ability to fulfill its financial obligations both in the short and long term, or to measure the extent to which the company is financed with debt (Wiagustini, 2013: 85). Leverage can be measured using the debt to equity ratio (DER).

\section{HYPOTHESIS}

3.1. The relationship between firm size and hedging decision making. Company size or firm size is the size of a company which can be seen from the amount of sales value, equity value and total asset value. Company size is used as an indicator to measure how much a company has grown in terms of its total asset value (Saraswati, 2019). 
Large companies will act carefully in managing their companies and do more hedging (Anniyati et al., 2018). Previous research conducted by Windari and Purnawati (2019), Anniyati et al., (2019), and research by Saraswati and Suryantini (2019), found that Firm Size has a positive and significant effect on hedging decisions. This positive effect means that a company in its capital structure, when it has more capital, is financed by debt than its own capital, of course, can increase the risk borne by the company. In order to avoid fluctuations in foreign exchange rates, companies tend to use hedging to minimize risks arising from exchange rate fluctuations that have an impact on the company.

H1: Firm Size has a positive effect on Hedging Decision Making.

3.2. The relationship between profitability and hedging decision making according to Kasmir (2015: 22), the definition of profitability is the ratio to assess a company's ability to look for profits or profits in a certain period. This ratio can also provide a measure of the level of effectiveness of company management which can be shown from the profits obtained from sales or from investment income. The high risk that a company will experience when expanding its market share will encourage the company to hedge.

This statement is reinforced by the results of research conducted by Saraswati and Suryantini (2019) and Jiwandhana and Triaryatu (2016) which found that profitability has a positive and significant effect on hedging decision making.

H2: Profitability has a positive effect on Hedging Decision Making.

3.3. The relationship between liquidity and hedging decision making the more liquid a company is, the smaller the risk of failure of the company in fulfilling its short-term obligations so that the threat of financial difficulties is also small which will reduce the company's hedging activities. Liquidity has a negative and significant effect on hedging decisions. This statement is in accordance with the results of previous research conducted by Windari and Purnawati (2019) and Ariani's research (2017), which found that liquidity had a negative and significant effect on hedging decision making. Based on the previous explanation, the hypothesis regarding the relationship between liquidity and hedging decisions is that there is a negative and significant relationship.

H3: Liquidity has a negative effect on hedging decision making.

3.4. The relationship between leverage and hedging decision making leverage measures the extent to which a company uses debt financing. The more a company uses debt (high leverage) in the form of foreign currency in its capital structure, the more likely the company is to hedge, because companies with higher leverage ratios allow companies to face the risk of financial difficulties (Jiwandhana and Triaryati, 2016).

The higher the debt owned by the company requires the company to be careful in carrying out the company's operational activities, especially when conducting international transactions in order to avoid fluctuations in foreign exchange rates, therefore companies tend to use hedging to minimize risks arising from exchange rate fluctuations that have an impact on the company.

H4: Leverage has a positive effect on Hedging Decision Making.

\section{RESEARCH METHODOLOGY}

This study uses a quantitative method with a causality approach. The population of this study were 10 pharmaceutical companies listed on the Indonesia Stock Exchange in 2009-2018. The sampling technique in this study was purposive sampling with predetermined criteria, so that the number of data collected was 40 samples consisting of 4 companies with a period of 10 years. With details of 4 companies as shown in table 1:

Table 1.

Research Sample Results Based on the Selection Process.

The variables used in this study are:

X1: Firm Size

X2: Profitability

$\mathrm{X} 3$ : Liquidity

$\mathrm{X} 4$ : Leverage

Y1: Hedging Decision

Firm size, profitability, liquidity, and leverage as independent variables and hedging decisions as the dependent variable. 
Table 2.

Operational Variables.

Variable Operations

Operasi Variabel

\begin{tabular}{ccc}
\hline Variables & Measurement & Size Scale \\
\hline $\begin{array}{c}\text { Firm Size } \\
(\mathrm{X} 1\end{array}$ & Ln (Total Asset $)$ & Ratio \\
\hline $\begin{array}{c}\text { Profitability } \\
(\mathrm{X} 2)\end{array}$ & $R O A=\frac{\text { Earning After Tax }}{\text { Total Assets }}$ & Ratio \\
\hline $\begin{array}{c}\text { Liquidity } \\
(\mathrm{X} 3)\end{array}$ & $C R=\frac{\text { Current Assets }}{\text { Current Liablities }}$ & Ratio \\
\hline $\begin{array}{c}\text { Leverage } \\
(\mathrm{X} 4)\end{array}$ & $D E R=\frac{\text { Total Liabilities }}{\text { Total Equity }}$ & Ratio \\
\hline
\end{tabular}

Hedging Variables dummy to do hedging $=1 \quad$ Interval

(Y) Do not do hedging $=0$

The data analysis used was quantitative data analysis. Quantitative data analysis is a form of analysis that uses numbers and calculations using statistical methods, then the data must be classified into certain categories using certain tables, to make it easier to analyze using the SPSS 25 program as a tool to regress the formulated model. The steps taken in this research are as follows:

1. Descriptive Analysis

In this study, descriptive statistics were carried out by calculating the average. The calculated average (mean) is a value obtained by dividing all observed values by the number of observations. The calculated average is formulated as follows:

Information:

$$
X=\frac{X 1+X 2+\cdots+X i+X n}{n}
$$

$\mathrm{X}=$ mean data

$\mathrm{Xn}=\mathrm{nth}$ variable

$\mathrm{n}=$ amount of

2. Test Prerequisite Analysis

The prerequisite analysis was tested before carrying out the logistic regression analysis. The prerequisite used in this study is a multicollinearity test.

3. Regression Analysis (Logistic Regression)

Logistic regression is used because this study has a dependent variable that is measured using dummy data. According to Bambang Suharjo (2013: 158), the logistic regression equation can be stated as follows:

$$
\log \frac{\mathrm{p}}{1-\mathrm{p}}=\beta 0+\beta x 1+\beta x 2+\beta x 3+\beta x 4
$$

Information:

$$
\log \frac{\mathrm{p}}{1-\mathrm{p}}=\text { hedging }
$$

$\beta 0=$ constant

$\mathrm{X} 1=$ Firm Size ratio

$\mathrm{X} 2=$ Profitability ratio

$\mathrm{X} 3=$ liquidity ratio

$\mathrm{X} 4$ = leverage ratio

While the prediction model is:

$$
P(y)=\frac{1}{1+e^{-\left[b_{0}+b_{i} X_{i}\right]}}
$$

Through the prediction model, the company is predicted to hedge if $\mathrm{P}>0.05$ where:

$\mathrm{P}=$ probability of hedging

$\mathrm{bi}=$ logistic regression coefficient

$\mathrm{Xi}=$ independent variable

$\mathrm{e}=$ natural number $(2,718282)$

The simultaneous hypothesis testing design is:

H04: $(\beta 1=\beta 2=\beta 3=\beta 4=0)$ Liquidity proxied by the current ratio, leverage proxied by the debt to equity ratio, and profitability proxied by return on assets do not simultaneously affect hedging

Ha4: $(\beta 1=\beta 2=\beta 3=\beta 4 \neq 0)$ Liquidity proxied by the current ratio, leverage proxied by the debt to equity ratio, 
and profitability proxied by return on assets jointly affect hedging

The criteria for acceptance or rejection of the null hypothesis (H0) are rejecting $\mathrm{H} 0$ at the error level $\alpha$ and degrees of freedom $(\mathrm{db}=\mathrm{p}=$ number of parameters $)$ if $\chi^{2}$ count $>\chi^{2}(1-\alpha)$ : $\mathrm{p}$.

If $\mathrm{HO}$ is accepted, it means that there is no effect of the independent variable simultaneously on the dependent variable. Vice versa, if $\mathrm{HO}$ is rejected, it means that the effect of the independent variable on the dependent variable is considered to be simultaneously influential.

As for knowing the significance seen from the significance value of the partial regression results with the significance set in the study. The significance set in this study is $\alpha=5 \%$ or 0.05 . If the significance value in the study $>0.05$, it is not significant, if the significance value $<0.05$, it is significant. This study uses a logistic regression model because logistic regression is suitable for research where the dependent variable is categorical (nominal or non-metric).

The logistic model used in this study is described as follows:

Feasibility test of the whole model (Overall Fit Model Test)

a. Test the whole model (Overall Model Fit)

b. Eligibility of Regression (Goodness of Fit Test)

c. Prediction Accuracy (Classification Matrix)

d. Cox and Snell's R Square and Nagelker's R Square coefficients

e. Research Hypothesis Test.

\section{RESEARCH RESULTS.}

Descriptive Statistics Test.

Table 4.1 Descriptive Statistical Analysis Results.

Statistics

\begin{tabular}{|c|c|c|c|c|c|c|}
\hline & & firm_size & profitabilitas & likuiditas & leverage & hedging \\
\hline \multirow[t]{2}{*}{$\mathrm{N}$} & Valid & 40 & 40 & 40 & 40 & 40 \\
\hline & Missing & 0 & 0 & 0 & 0 & 0 \\
\hline \multicolumn{2}{|c|}{ Mean } & 28.0615 & 7.3787 & 241.5975 & 74.2193 & 0.25 \\
\hline \multicolumn{2}{|c|}{ Std. Deviation } & 1.65272 & 7.76225 & 100.91533 & 50.70596 & 0.43 \\
\hline \multicolumn{2}{|c|}{ Minimum } & 25.32 & -4.18 & 104.21 & 18.64 & 0 \\
\hline \multicolumn{2}{|c|}{ Maximum } & 30.52 & $33-.63$ & 465.77 & 190.62 & 1 \\
\hline
\end{tabular}

Source: SPSS Version 25, Data Processed (2020).

The descriptive test results in this study show that the highest firm size was achieved by PT Kalbe Farma Tbk in 2018 and the lowest firm size was achieved by PT. Pyridam Farma Tbk in 2009. The average firm size for pharmaceutical sector companies is 28.06 .

On the Profitability variable the average value achieved was $7.37 \%$. The company with the highest profitability was achieved by PT. Kimia Farma (Persero) Tbk in 2015, and the company with the lowest profitability was achieved by PT. Indofarma (Persero) Tbk in 2013.

In the liquidity variable, the average value achieved is $241.59 \%$. The company with the highest liquidity was achieved by PT. Kalbe Farma Tbk in 2018, and the company with the lowest liquidity was achieved by PT. Indofarma (Persero) Tbk Year 2017.

In the Leverage variable, the average value achieved is $74.21 \%$. The company with the highest leverage was achieved by PT. Indofarma (Persero) Tbk in 2017, and the company with the lowest Leverage was achieved by PT. Kalbe Farma Tbk in 2018. In variable hedging, it is known that the average value achieved is 0.25.

Test Prerequisite Analysis

This study uses a multicollinearity test in the analysis prerequisite test process. The calculation results show that all independent variables have a Tolerance value $\geq 0.10$. The VIF value based on the calculation results shows that all independent variables have a VIF value $\leq 10$. Thus, it can be concluded that all independent variables in this study do not occur multicollinearity. 
Logistic Regression Test

Test the Whole Model.

Table 4.2.

Fit Test Results 1.

Iteration History ${ }^{\mathrm{a}, \mathrm{b}, \mathrm{c}}$

Coefficients

Iteration -2 Log likelihood Constant

\begin{tabular}{|c|c|c|}
\hline Step 01 & 45.061 & -1.000 \\
\hline 2 & 44.987 & -1.096 \\
\hline 3 & 44.987 & -1.099 \\
\hline 4 & 44.987 & -1.099 \\
\hline
\end{tabular}

Source: SPSS 25, Data Processed (2020)

It is known that the value of -2 Log likelihood Block Number $=0$ is 44,987 .

Table 4.3

Fit Test Results 2.

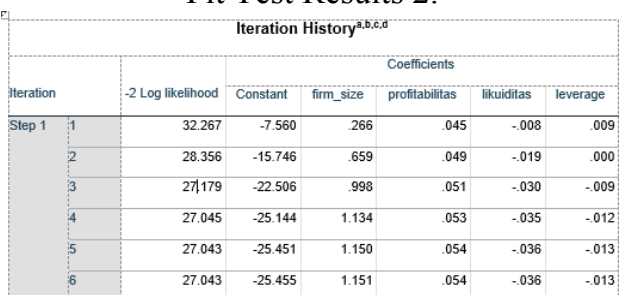

Source: SPSS 25, Data Processed (2020).

Furthermore, this value will be compared with 2 Log Likelihood Block Number $=1$, so that the first block value (Block Number $=0$ ) is 44,987 and -2 LL in the second block (Block Number $=1$ ) is 27,043. With these results it can be concluded that the second regression model is better, because there is a decrease in value from the first block to the second block (Ghozali, 2018).

Table 4.4

Omnibus Test Results.

\section{Omnibus Tests of Model Coefficients}

\begin{tabular}{|c|c|c|c|c|}
\hline & & Chi-square & df & Sig. \\
\hline \multirow[t]{3}{*}{ Step 1} & Step & 17.944 & 4 & .001 \\
\hline & Block & 17.944 & 4 & .001 \\
\hline & Model & 17.944 & 4 & .001 \\
\hline
\end{tabular}

Source: SPSS 25, Data Processed (2020).

Furthermore, the Omnibus Test was tested and the chi-square value obtained was 17,944 and with a significant value of $0.001<0.05$. This shows that together the independent variables (Firm Size, Profitability, Liquidity and Leverage) affect the hedging decision.

\section{Regression Due Diligence.}

Table 4.5

Hosmer and Lomeshow's Test Results.

\begin{tabular}{lr|rrr}
\multicolumn{5}{c}{ Hosmer and Lemeshow Test } \\
Step & Chi-square & df & Sig. \\
\hline 1 & 5.860 & & 8 & .663 \\
\hline
\end{tabular}

Source: SPSS 25, Data Processed (2020).

Assessment of the feasibility of the regression model was carried out using the Hosmer and Lomeshow's Goodness of Fit Test, and obtained a Chi square of 5,860 with a significance value of 0.663 and df 8 . From these results it can be seen that the significant value is greater than 0.05 so that the null hypothesis is accepted, which means the model can predict the value of observation and the model is acceptable. So it can be concluded that the logistic regression model used has met the data adequacy (fit). 


\section{Prediction Accuracy Test.}

Table 4.6

Prediction Accuracy Test Results.

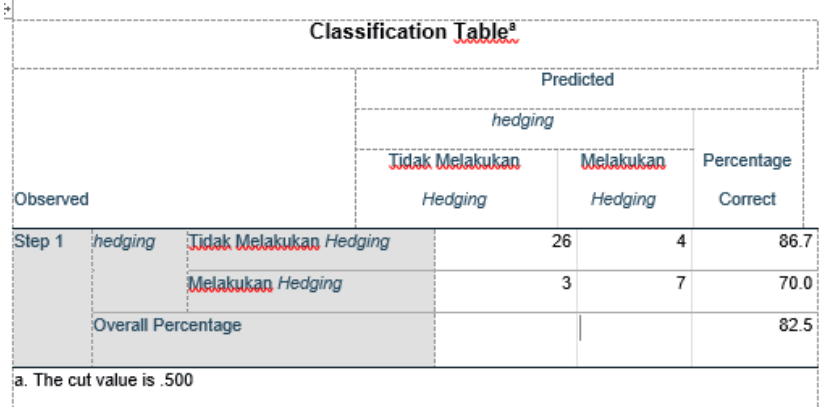

Source: SPSS 25, Data Processed (2020)

The table for the accuracy of the classification prediction shows that of the 30 observation units that did not actually hedge, the "observed line" was predicted by the model: correct, 26 observation units as "Not hedging" and 4 observation units as "Hedging". Therefore the classification truth value is $86.7 \%$.

Meanwhile, of the 10 observation units that actually performed hedging, the observed line was predicted by the model: exactly 3 observations were "Didn't Hedging" and 7 observation units were "Hedging". Therefore the classification truth value is $70 \%$. The overall percentage value is $82.5 \%$.

\section{Determination Coefficient Test (Nagelkerke's $R$ Square)}

Table 4.7

Determination Coefficient Test Results.

\section{Model Summary}

Step -2 Log likelihood Cox \& Snell R Square Nagelkerke R Square

\begin{tabular}{rrr}
\hline 1 & .661 & .735 \\
\hline
\end{tabular}

From the results of this test, it is obtained that the test results of the -2Log Likelihood model produce 27,043 from the coefficient of determination seen from the Nagelkerke R Square is $0.735(73.5 \%)$ and the Cox \& Snell R Square value is $0.661(66.1 \%)$. This means that the independent variables, namely Firm Size, Profitability, Liquidity and Leverage, are able to explain the variation of the dependent variable on hedging decisions by $73.5 \%$. While the remaining $26.5 \%$ is explained by factors outside of this study.

\section{Research Hypothesis Test.}

Table 4.8

Hypothesis Test Results.

\begin{tabular}{|c|c|c|c|c|c|c|}
\hline & \multirow[b]{2}{*}{ B } & \multirow[b]{2}{*}{ S.E. } & & \multirow[b]{2}{*}{ df } & \multirow[b]{2}{*}{ Sig. } \\
\hline & & & & Wald & & \\
\hline \multirow[t]{5}{*}{ Step $1^{\circ}$} & firmosize & 1.151 & .689 & 2.791 & 1 & .005 \\
\hline & profitabilitas & .354 & .098 & 1.301 & 1 & .023 \\
\hline & Vkuiditas & -2.036 & .018 & 3.850 & 1 & .002 \\
\hline & leverage & .313 & .022 & .335 & 1 & .033 \\
\hline & Constant & 25.455 & 16.878 & 2.274 & 1 & .000 \\
\hline
\end{tabular}

Source: SPSS 25, 2020.

In this study, hedging decisions are measured based on dummy variables so that there are differences in units and quantities to the independent variables, causing the regression equation to be made in a natural logarithmic (Ln) model (Ghozali, 2018)

The constant variable of the logistic regression model has a negative coefficient of 25.455.

The Firm Size variable shows the coefficient value of 1.151 in a positive direction. The Firm Size significance value shows a value of $0.005<0.05$, which means significant.

The profitability variable shows a coefficient value of 0.354 in a positive direction. The significance value of Profitability shows a value of $0.023<0.05$, which means that it is significant.

The liquidity variable shows a coefficient value of $-2,306$ in a negative direction. The liquidity significance value shows a value of $0.002<0.05$, which means significant.

The leverage variable shows a coefficient value of 0.313 in a positive direction. The significance value of leverage shows a value of $0.033<0.05$, which means that it is significant. 


\section{DISCUSSION OF RESEARCH RESULTS.}

Effect of Firm Size on Hedging Decisions

The results showed that Firm Size has a positive and significant effect on hedging decisions. This is because the Firm Size significance value shows a value of $0.005<0.05$ (Ghozali, 2018).

The size of the company can be seen from the size of the assets owned by the company, the bigger the company's operational activities, the higher it will be. Large companies emphasize more on strict risk management, therefore companies do not want to experience losses due to the impact of export and import. While small companies are more faced with limited information and the transaction costs incurred are also getting bigger, making it possible to do hedging, but small companies do not yet have the expertise and technology to manage foreign exchange exposure.

The bigger the company will tend to use hedging activities to protect the assets that exist in the company because the bigger the company the risk it faces will also be greater. This statement is reinforced by the results of previous research conducted by Windari and Purnawati (2019), Anniyati et al., (2019), and research by Saraswati and Suryantini (2019), which found that Firm Size has a positive and significant effect on hedging decisions.

\section{The Effect of Profitability on Hedging Decisions.}

The results showed that profitability had a positive and significant effect on hedging decisions. This is because the significance value of Profitability shows a value of $0.023<0.05$ (Ghozali, 2018).

According to Jiwandhana (2016), the level of profitability has a positive and significant effect on hedging decisions. This is because companies with a high level of profitability tend to expand their business more quickly, because the international market is dynamic, so any changes can cause losses for companies that carry out large transactions. Companies will need hedging to reduce this risk. So that the hedging decision can increase the company's profitability. The results of this study are in line with previous research conducted by Saraswati and Suryantini (2019) which found that profitability has a positive and significant effect on hedging decision making.

\section{The Effect of Liquidity on Hedging Decisions.}

The results showed that liquidity had a negative and significant effect on hedging decisions. This is because the liquidity significance value shows a value of $0.002<0.05$ (Ghozali, 2018).

Liquidity shows the company's ability to meet short-term obligations on time. A company can be said to be liquid if the current assets owned by the company are worth more than the debt. High liquidity indicates that the company is able to face risks by using its reserve funds, so the use of hedging is low. If the liquidity value of a company is high, the company will conduct low hedging because of the low financial risk.

The results of this study are in line with previous research conducted by Windari and Purnawati (2019) and Ariani's research (2017), which found that liquidity had a negative and significant effect on hedging decision making.

\section{The Effect of Leverage on Hedging Decisions.}

The results showed that Leverage has a positive and significant effect on hedging decisions. This is because the significance value of Leverage shows a value of $0.033<0.05$ (Ghozali, 2018).

Leverage measures the extent to which a company uses debt financing. The more a company uses debt (high leverage) in the form of foreign currency in its capital structure, the more likely the company is to hedge, because companies with higher leverage ratios allow companies to face the risk of financial difficulties (Jiwandhana and Triaryati, 2016). A company needs capital in the form of debt or equity if the company wants to grow.

The advantage of using debt in foreign currency is that the interest offered is lower than loans in rupiah, while the disadvantage is that the foreign currency risk that the company will bear will be large because if the foreign exchange rate appreciates against the local currency exchange rate, the foreign currency debt will suppress, even eliminating the company's profit margins. This reduced profit occurs because the company will need more local currency to pay off the foreign currency debt. The greater the risk of foreign exchange fluctuations that a company bears due to the use of debt in foreign currency, the more hedging is needed to minimize this risk.

The results of this study are in line with previous research conducted by Windari and Purnawati (2019), Saraswati and Suryantini (2019) and Ariani (2017) which found that leverage has a positive and significant effect on hedging decision making.

\section{CONCLUSIONS AND SUGGESTIONS.}

Conclusion

1) Firm Size has a positive and significant effect on hedging decisions.

2) Profitability has a positive and significant effect on hedging decisions.

3) Liquidity has a negative and significant effect on hedging decisions.

4) Leverage has a positive and significant effect on hedging decisions. 
Suggestion

1) Pharmaceutical companies that will make hedging decisions are expected to pay attention to internal company information, namely Firm Size, Profitability, Liquidity and Leverage.

2) It is recommended for pharmaceutical companies to hedge to protect their Firm Size from wide-ranging operational activities that could be more risky.

3 ) It is recommended for pharmaceutical companies to hedge to increase the profitability achieved by the company. This is because hedging activity has reduced the risk of loss.

4) It is recommended for pharmaceutical companies to use hedging accreditation if the company has a low level of liquidity.

5) It is recommended that pharmaceutical companies engage in hedging activities when they have a high proportion of debt.

6) Investors who will invest in pharmaceutical companies listed on the Indonesia Stock Exchange can make an investment selection or investment selection first by taking into account the variables related to hedging decisions, such as Firm Size, Profitability, Liquidity and Leverage owned by the company. .

7) For further researchers it is recommended to add other internal company variables or to use the same variables in this study but using different measuring instruments, and it is recommended to use different industries and to extend the research period. This is because the Nagelkerke R Square value is $73.5 \%$ so that the remaining $26.5 \%$ can be explained by other variables outside the research model.

\section{BIBLIOGRAPHY.}

Anniyati, H., Hermanto., \& Hidayati, S.A. (2019). The Influence of Firm Size, Financial Distress, Debt Level, and Managerial Ownership on Hedging Decisions in Manufacturing Companies Listed on the Indonesia Stock Exchange. Journal of Magister Management of Mataram University, Volume 9 - Issue 1 - March 2020.

Ariani, Ni Nengah Novi and Gede Merta Sudiartha. (2017). The Influence of Leverage, Profitability, and Liquidity on Hedging Decisions of Mining Sector Companies on the Indonesia Stock Exchange. E-Journal of Management of Udayana University, Vol. 6, No.1, 2017: 347-374.

Brigham, E.F., \& Houston J.F. (2018). Fundamentals of Financial Management (Ali Akbar Yulianto, Translator). Jakarta: Four Salemba

Fahmi, Irham. (2015). Financial Statement Analysis. Alfabeta, Bandung.

Fathoni \& Suryani (2017). Islamic Perspective Hedging: Comparison of Indonesia and Malaysia. Journal Vol. 11, No.2, December 2017.

Ghazali, Imam. (2018). Multivariate Analysis Application with IBM SPSS 25 Program. Nine Edition. Publishing Agency of Diponegoro University, Semarang.

Guniarti, Fay. (2014). Factors Affecting Hedging Activities with Foreign Exchange Derivative Instruments. Journal of Management Dynamics. JDM Vol. 5.

Hady, Hamdy. (2016). International Financial Management. Fourth Edition. Mitra Wacana Media, Jakarta.

Hosmer, D.W Jr., Lemeshow S, and Studivant R.X. (2013). Applied Logistic Regression. Wiley New Jersey.

Hanafi, Mamduh. (2013). International Financial Management, BPFE, Yogyakarta.

Hanafi, Mamduh and Abdul Halim. (2016). Financial Statement Analysis, Fifth Edition. STIM YKPN, Yogyakarta.

Hidayah, Naímatul and Prasetiono. (2016). Determining Factors of Companies Making Hedging Decisions on Foreign Exchange Derivatives (T-Shirt Study on Manufacturing Companies Listed on the IDX for the 20112014 Period). Diponegoro Journal of Management, Vol. 5, No.3, 2016: 2337-3792.

Harahap, Sofyan Safri. (2015). Critical Analysis of Financial Statements. Issue 1-10. Rajawali Press, Jakarta.

James, c. Van Horne and John M. Wachowicz. (2012). Principles of Financial Management. Salemba Empat, Jakarta.

Jiwandhana, RM Satwika Putra and Nyoman Tiaryati. (2016). The Effect of Leverage and Profitability on Hedging Decisions of Manufacturing Companies in Indonesia. E-Journal of Management of Udayana University, Vol. 5, No.1, 2016: 31-58.

Kieso, Weygandt dan Warfield. (2011). Intermediate Accounting IFRS Edition Volume 2. Unites States: John Wiley \& Sons.

Krisdian, Ni Putu Candra and Ida Bagus Badjra. (2017). The Influence of Company Size, Debt Level, and Financial Difficulties on Hedging Decisions in Indonesian Manufacturing Companies. E-Journal of Management of Udayana University, Vol. 6, No.3, 2017: 1452-1477.

M, Praveen Bhagawan and Jijo Lukose P.J., (2017). The Determinants of Currency Derivatives Usage Among Indian Non-Financial Firms: An Empirical Study, Studies in Economics and Finance.

Madura, Jeff. (2000). International Corporate Financial Management. Salemba Empat, Jakarta.

Mediana, Ima and Harjum Muharam. (2016). Analysis of Factors Affecting Hedging Decision Making Using Derivative Instruments (Case Study of Manufacturing Companies and Energy and Mineral Resources Companies Listed on the IDX 2010-2014). Diponegoro Journal of Management, Vol. 5, No.2, 2016: 2337 - 
3792.

Raras, Kinasih and Dewa Putra Krishna Mahardika. (2019). The Effect of Liquidity, Leverage, and Rupiah Exchange Rate on the Use of Derivative Instruments as a Hedging Decision. MEA Scientific Journal (Management, Economics \& Accounting), Vol. 3, No. 1, 63-80.

Saraswati, Ayuningtyas Putri and Ni Putu Santi Suryantini. (2019). The Effect of Leverage, Firm Size, Profitability on Hedging Decisions in Manufacturing Companies on the Indonesia Stock Exchange. Management EJournal, Vol. 8, No. 5, 2019: 2999-3027.

Sartono, Agus. (2012). Financial Management Theory and Applications. Fourth Edition. BPFE, Yogyakarta.

Sofar Silaen and Widiyono. (2013). Social Research Methods for Thesis and Thesis Writing. In Media, Jakarta.

Sugiyono. (2018). Management Research Methodology. Alfabeta, Bandung.

Suharjo, Bambang. (2013). Applied Statistics. Graha Ilmu, Yogyakarta.

Sutedi, Adrian. (2012). Derivative Products and Legal Aspects. Alfabeta, Bandung.

Windari, I Gusti Made Diah and Ni Ketut Purnawati. (2019). The Effect of Leverage, Company Size, and Liquidity on Hedging Decisions in Manufacturing Companies listed on the IDX. E-Journal Management, Vol. 8, No. 8, 2019: 4815-4840.

Zulkifli, Endri, Augustina Kurniasih, Determinants of the Internal Dividend Payout Ratio of Pharmaceutical Companies Listed on the Indonesian Stock Exchange, Journal of Finance and Banking, 21 (2): 238-252, 2017. 